\title{
Natural forest expansion into suburban countryside: Gained ground for a green infrastructure?
}

\author{
Anna Barbati ${ }^{\mathrm{a}, *}$, Piermaria Corona ${ }^{\mathrm{a}}$, Luca Salvati $^{\mathrm{b}}$, Lorenza Gasparella $^{\mathrm{a}}$ \\ a Department for Innovation in Biological, Agro-food and Forest systems (DIBAF), University of Tuscia, Via S. Camillo De Lellis, snc I-01100 Viterbo, Italy \\ ${ }^{b}$ Consiglio per la Ricerca e la sperimentazione in Agricoltura, via della Navicella 2-4, I-00184 Rome, Italy
}

\section{A R T I C L E I N F O}

\section{Keywords:}

Forest expansion

Mediterranean region

Morphological Spatial Pattern Analysis

Suburban landscape

\begin{abstract}
A B S T R A C T
Understanding patterns of natural forest expansion in rural regions under the influence of urbanization processes is crucial for integrated spatial planning across the urban-to-rural gradient. As a matter of fact, forest expansion is the only natural process that may counteract the consumption of the ecosystem capital and ecosystems services of rural lands due to uncontrolled urban sprawl. The paper addresses this topic in the paradigmatic case study of the countryside of Rome (Italy), characterized by counter dynamics of forest expansion and suburbanization. Morphological Spatial Pattern Analysis (MSPA) is applied to classify the forest landscape structure twice (1974 and 2008) according to seven categories (core, islet, perforation, edge, loop, bridge, branch) with different potential functional role as elements of a green infrastructure. Main findings are: (i) forest cover increased from $11 \%$ to $16 \%$ between 1974 and 2008; forest land uptake exceeds $4 \%$ of total study area, but shows a slower pace than the growth of built-up areas (10\%); (ii) forest expansion has been to a large extent achieved by "sprawling" of islets ( $1.6 \%$ of the study area) along the stream network; (iii) more compact forest expansion has taken place on $0.2 \%$ of the study area in the form of additions to existing core areas or creation of new ones and (iv) the establishment of a network of protected areas nearby Rome has played a key role for the conservation and further expansion of core areas; yet, local loss of 1974 core areas stocks in a few protected areas indicates need of further law enforcement to ensure effective protection of the natural capital from degradation processes or even land conversion into built-up areas.

Results calls for future in-depth investigations on the quality of newly created or maintained forest resource stocks associated to different spatial pattern structures. Integrated spatial planning strategies are outlined for the conservation of ecosystem capital and ecosystems services provided by forests, as major components of Rome's green infrastructure.
\end{abstract}

(C) 2012 Elsevier GmbH. All rights reserved.

\section{Introduction}

The traditional Mediterranean landscape includes compact urban areas, biodiversity-rich agricultural farmland, pastures and different types of woodlands, and the rocky mountain belt (Brouwer et al., 1991). The spatial pattern of these land cover classes mainly depends on bio-physical factors, including climate and soil quality (Falcucci and Maiorano, 2008). Urban sprawl and withdrawal of farming have significantly altered the urban-to-rural gradient in the past decades. Agricultural land has been lost at the 'margins' of such a gradient (EEA, 2006a): at the urban interface, through urbanization, and on marginal rural areas, through natural forest expansion from surrounding woodlands.

Understanding patterns of natural forest expansion in rural regions under the influence of urbanization process, the so-called

\footnotetext{
* Corresponding author. Tel.: +390761357406.

E-mail address: barbati.sisfor@unitus.it (A. Barbati).
}

suburban countryside, is crucial for integrated spatial planning across the urban-to-rural gradient. As a matter of fact, forest expansion is the only natural process that may counteract the consumption of the ecosystem capital and ecosystems services of rural lands, due to uncontrolled urban sprawl (EEA, 2006b).

Dynamics of forest expansion on marginal rural lands, a process also known as old-field succession, has been extensively studied in the Mediterranean region (Tatoni et al., 1994; Debussche et al., 1996; Bonet, 2004; Pugnaire et al., 2006). Abandoned farmland can be recolonized by forest vegetation over a few decades through a sequence of rapid transitions from a grass-dominated to shrub finally to forest-dominated phase (Gray et al., 1987; Prach et al., 2001; Quézel and Médail, 2003; Otto et al., 2006). Forest expansion on abandoned farmland is known to be driven by several natural and anthropogenic variables: altitudinal climate gradient, soil and vegetation characteristics, former land uses, presence of propagule sources, seedbank, and so forth. It must be observed, though, that driving forces of natural forest expansion vary widely in forest theory (Taverna et al., 2004). However, as shown by Corona et al. 